\title{
Rapid decomposition of traditionally produced biochar in an Oxisol under savannah in Northeastern Brazil
}

\author{
Edvaldo Sagrilo $^{\mathrm{a}, 1}$, Tatiana F. Rittl ${ }^{\mathrm{b}, *, 1}$, Ellis Hoffland ${ }^{\mathrm{b}}$, Bruno J.R. Alves ${ }^{\mathrm{c}}$, Herony U. Mehl ${ }^{\mathrm{a}}$, Thomas W. Kuyper ${ }^{\mathrm{b}}$ \\ a Embrapa Mid-North, Av. Duque de Caxias 5650, 64006-220 Teresina, Piauí,Brazil \\ ${ }^{\mathrm{b}}$ Department of Soil Quality, Wageningen University, PO Box 47, Wageningen 6700 AA, The Netherlands \\ c Embrapa Agrobiology, km 47, Antiga Rodovia Rio - São Paulo, Seropédica 23890-000, Rio de Janeiro, Brazil
}

\section{A R T I C L E I N F O}

\section{Article history:}

Received 26 March 2015

Received in revised form 12 August 2015

Accepted 13 August 2015

Available online 18 August 2015

\section{Keywords:}

Pyrogenic organic matter

Soil organic carbon

Carbon sequestration

Recalcitrance

Stable isotope

Oxisols

\begin{abstract}
A B S T R A C T
Soil amendment with biochar has been claimed as an option for carbon (C) sequestration in agricultural soils. Most studies on biochar/soil organic carbon (SOC) interactions were executed under laboratory conditions. Here we tested the stability of biochar produced in a traditional kiln and its effects on the stocks of native SOC under field conditions. The biochar was characterized using pyrolysis-gas chromatography-mass spectrometry, and then added to an Oxisol under savannah climate. This soil was amended with 0,5,10,20 and $40 \mathrm{Mg} \mathrm{ha}^{-1}$ of biochar in a randomized complete block design with four replications and cultivated with soybean over four cropping seasons (CSs; 120 days each). Soil samples from the $0-10 \mathrm{~cm}$ top layer were collected at the end of the first and fourth $\mathrm{CSs}$ and analyzed for $\mathrm{CO}_{2}$ emissions, isotopic $\mathrm{C}$ abundance $\left({ }^{13} \mathrm{C} /{ }^{12} \mathrm{C}\right.$ ratio) and enzymatic activity (fluorescein diacetate and dehydrogenase). The biochar showed a low degree of thermal modification. Its relative decomposition rate was higher $\left(\mathrm{k}=0.32-1.00\right.$ year $\left.^{-1}\right)$ than generally claimed $(\mathrm{k}=0.005-$ 0.0005 year $\left.^{-1}\right)$, and higher than the decomposition of native SOC $\left(k=0.22\right.$ year $\left.^{-1}\right)$. Addition of biochar did not affect the stocks of native SOC. Our findings highlight the need for critically reviewing the potential of locally produced biochar to sequester $\mathrm{C}$.
\end{abstract}

C 2015 Elsevier B.V. All rights reserved.

\section{Introduction}

Biochar is the solid product of carbonization of organic materials at low oxygen concentration, intentionally produced to be applied in the soil (Lehmann and Joseph, 2009). The deliberate production and addition of biochar in soil distinguishes it from other carbonized products like charcoal and pyrogenic organic materials (PyOM). Soil amendment with biochar has been advocated as a climate-smart solution for agriculture, reducing atmospheric concentrations of carbon (C) dioxide (Woolf et al., 2010), thereby attracting the interest of the carbon market (Lehmann, 2007). When incorporated into the soil, biochar is expected to contribute to the recalcitrant soil organic carbon (SOC) pool (Lehmann et al., 2006). The decomposition rate of biochar depends on the soil environment to which biochar is applied. Carbonized products decompose faster under warmer and drier conditions than under cooler and moister conditions (Glaser and Amelung, 2003; Nguyen and Lehmann, 2009). In well-aerated tropical sandy soils, charcoal can be degraded in decades (Bird et al., 1999; Zimmermann

\footnotetext{
* Corresponding author.

E-mail addresses: edvaldo.sagrilo@embrapa.br (E. Sagrilo), tatarittl@gmail.com (T.F. Rittl), ellis.hoffland@wur.nl (E.Hoffland), bruno.alves@embrapa.br (B.J.R. Alves), herony.mehl@embrapa.br (H.U. Mehl), thom.kuyper@wur.nl (T.W. Kuyper).

1 These authors contributed equally to this work
}

et al., 2012). These decomposition studies used charcoal produced by fire events (Bird et al., 1999; Glaser and Amelung, 2003; Nguyen et al., 2008; Zimmermann et al., 2012). It is not immediately evident that findings on charcoal degradation are relevant for the biochar debate, because one may assume that they are distinct types of materials. However, regarding to the physico-chemical properties, these materials are essentially the same, and therefore the mechanisms that control their decomposition in the soil. Furthermore, findings of biochar produced and incubated under controlled conditions cannot be easily extrapolated to field conditions. In order to apply and to scale up biochar use to mitigate climate change, biochar produced by traditional methods (e.g., in brick kilns) has to be tested under field conditions. This is especially relevant in countries like Brazil, where such charring methods still predominate (Duboc et al., 2007). Currently, there is a lack of field data on decomposition rates of biochar produced in traditional kilns.

Increases in $\mathrm{CO}_{2}$ emission following biochar additions in soils or PyOM produced from wildfires may result from the decomposition of part of these materials (Cross and Sohi, 2011; Hilscher et al., 2009; Jones et al., 2011; Méndez et al., 2013; Sagrilo et al., 2014; Smith et al., 2010; Zimmerman et al., 2011). This suggests that some carbonized products (PyOM, biochar or charcoal) may be less recalcitrant than expected (Knicker et al., 2013). In most studies however, it is not possible to distinguish whether the increased production of $\mathrm{CO}_{2}$ after biochar addition is due to degradation of biochar and/or of SOC. Isotope analysis 
is an effective way to identify the origin of the $\mathrm{C}$ in biochar-amended soils. Only few studies (Cross and Sohi, 2011; Hilscher and Knicker, 2011; Luo et al., 2011; Méndez et al., 2013; Smith et al., 2010; Zimmerman et al., 2011) used this tool to distinguish the origin of evolved $\mathrm{CO}_{2}$ from biochar-amended soils or the nature of the remaining $\mathrm{C}$ in the soil. However, these studies were performed predominantly under laboratory conditions and for short periods.

There is a lack of data from field experiments lasting for more than one cropping cycle. In our field study, we aimed to quantify changes in the biochar and SOC stocks over four soybean cropping seasons (CSs) in a $\mathrm{C}_{4}$ sandy Oxisol amended with different rates of biochar. The biochar was produced from $C_{3}$ woody species using traditional local charring methods. The biochar was characterized using pyrolysis-gas chromatography-mass spectrometry (Py-GC-MS). Changes in soil microbial activity were determined by changes in enzyme activity of fluorescein diacetate (FDA) and dehydrogenase (DHG). We used ${ }^{13} \mathrm{C}$ isotopic analysis to discriminate between $\mathrm{SOC}$ and biochar as the source of $\mathrm{CO}_{2}$ and to quantify the decomposition rates of native $\mathrm{SOC}$ and biochar.

\section{Materials and methods}

\subsection{Study site}

An experiment was carried out at the field station of Embrapa MidNorth in Parnaiba (UEP-Parnaiba), Brazil ( $3^{\circ} 05^{\prime} 18^{\prime \prime} \mathrm{S} ; 41^{\circ} 47^{\prime} 00^{\prime \prime} \mathrm{W} ; 52 \mathrm{~m}$ altitude). Regional climate is 'Aw' type (tropical with a dry season), according to Köppen classification. Local annual mean temperature is $27{ }^{\circ} \mathrm{C}$, mean precipitation is $1079 \mathrm{~mm}$ and relative humidity is $76.5 \%$ (Andrade Junior et al., 2005). Potential evapotranspiration (PET) was calculated using the software LocClim 1.10 (Fig. 1). Crops are generally planted in February-March under natural rainfall conditions and harvested in June or July. The soil was an Oxisol (USDA Soil Taxonomy), and due its proximity to the sea $(25 \mathrm{~km})$ the soil has an over layer of $40 \mathrm{~cm}$ of sand. The textural distribution of the topsoil was $886 \mathrm{~g} \mathrm{~kg}^{-1}$ of sand and $86 \mathrm{~g} \mathrm{~kg}^{-1}$ of clay dominated by kaolinite (1:1). Table 1 shows the main characteristics of the soil. The high base saturation of this soil is due the historic soil fertility management in the previous years. The native vegetation was a Caatinga-coastal phase (Melo et al., 2004). From 1995 to 2007 an experiment with tropical grass species had been set up. From 2007 to the beginning of this experiment (September 2011), the area remained under fallow, with grass-dominated spontaneous vegetation, which was cut once per year. The residues were left on the soil surface.

In early September 2011, the soil was harrowed twice with a heavy harrow. Four blocks were distinguished in which experimental plots of $2.0 \times 3.0 \mathrm{~m}$ were established allowing sprinkler lines between blocks

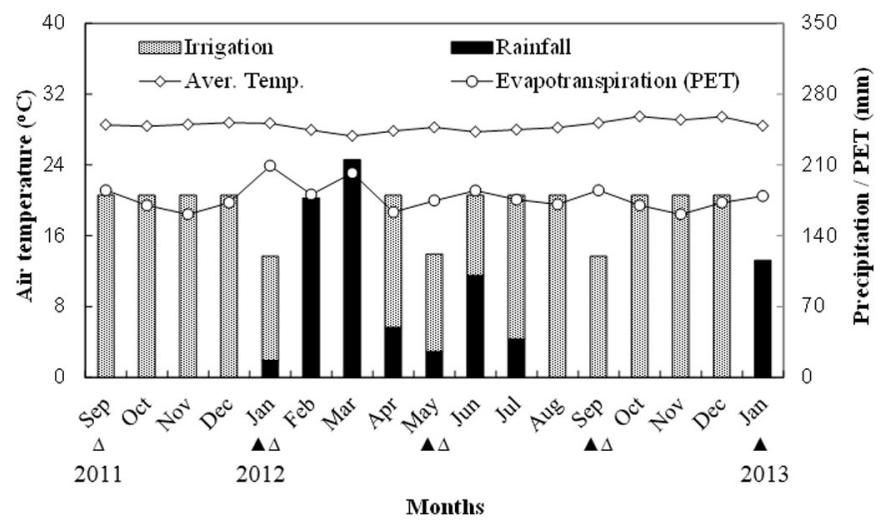

Fig. 1. Monthly average temperatures and total monthly precipitation from rainfall and irrigation during the experimental period. $\Delta$ indicates the sowing events; $\boldsymbol{\Delta}$ indicates the harvest events.
Table 1

Soil properties.

\begin{tabular}{ll}
\hline Soil properties & \\
\hline Organic $\mathrm{C}$ & $6.6 \mathrm{~g} \mathrm{~kg}^{-1}$ \\
$\mathrm{pH}\left(\mathrm{H}_{2} \mathrm{O}\right)_{1: 2: 5}$ & 5.9 \\
$\mathrm{~K}$ & $0.07 \mathrm{cmol}_{\mathrm{c}} \mathrm{kg}^{-1}$ \\
$\mathrm{Ca}$ & $2.0 \mathrm{cmol}_{\mathrm{c}} \mathrm{kg}^{-1}$ \\
$\mathrm{Mg}$ & $0.94 \mathrm{cmol}_{\mathrm{C}} \mathrm{kg}^{-1}$ \\
$\mathrm{Na}$ & $0.01 \mathrm{cmol}_{\mathrm{C}} \mathrm{kg}^{-1}$ \\
$\mathrm{Al}$ & $0.03 \mathrm{cmol}_{\mathrm{c}} \mathrm{kg}^{-1}$ \\
$\mathrm{H}+\mathrm{Al}$ & $2.08 \mathrm{cmol}_{\mathrm{C}} \mathrm{kg}^{-1}$ \\
$\mathrm{Sum}$ of bases & 3.01 \\
$\mathrm{CEC}$ & $3.42 \mathrm{cmol}_{\mathrm{c}} \mathrm{kg}^{-1}$ \\
Base saturation & $59.1 \%$ \\
Al saturation & $0.99 \%$ \\
\hline
\end{tabular}

1-2 and 3-4. Additional sprinkler lines were maintained at each side of the experimental area. Coarse residues of grass on the plots were removed from the top $10 \mathrm{~cm}$ with hoes and rake in order to facilitate the biochar mixing with soil and opening of furrows for planting. Seeds of soybean were planted at a density of 14 plants $\mathrm{m}^{-1}$, in five rows spaced $0.40 \mathrm{~m}$ from each other. Soybean sowing took place at each 4-month interval (120 days), for four successive cropping seasons (CSs 1-4), which was made possible due to irrigation. The year 2012 was unusually dry, with total rainfall of $625 \mathrm{~mm}$ - much lower than the average of $1079 \mathrm{~mm}$ - and for this reason, even in the rainy season, irrigation took place regularly, except in February and March (Fig. 1). After harvest of plants in each CS, soybean crop residues were removed from the plots.

\subsection{Biochar production}

The biochar was produced from native woody savannah $C_{3}$ plants (e.g., Curatella americana, Tabebuia spp., Parkia platycephala, Caryocar brasiliense) using a slow charring process ( $\sim 8 \mathrm{~h}$ ) in regionally used traditional kilns. These kilns (approximately $2.8 \mathrm{~m}$ high, 4-6 m diameter) are made from mud bricks and have a loading capacity of around $18 \mathrm{~m}^{3}$ of feedstock. Basic chemical analyses of biochar were performed using protocols adapted from standard soil analysis methods (EMBRAPA, 1997). Biochar $\mathrm{pH}$ was measured using a 1:2.5 (biochar: $\mathrm{H}_{2} \mathrm{O}$ ) solution. Electrical conductivity was measured using the "Saturated Paste Method" (Richards, 1954). Chemical properties of biochar are provided in Table 2 .

\subsection{Biochar characterization}

Pyrolysis-GC-MS of the biochar was performed at $750{ }^{\circ} \mathrm{C}$ for $10 \mathrm{~s}$, with a heating rate of $10^{\circ} \mathrm{C} \mathrm{ms}^{-1}$. This relatively high analytical pyrolysis temperature is the most suitable for biochar analysis using PyGC-MS (Kaal et al., 2009). Briefly, a biochar sample of 1-1.5 mg was placed in fire-polished quartz tubes with quartz wool on both ends and pyrolysed using a resistive heating Pt-filament CDS Pyroprobe 5250 Autosampler. The pyrolysis products were transferred into a $6890 \mathrm{~N}$ gas chromatograph (Agilent Technologies) by He $\left(1 \mathrm{ml} \mathrm{min}^{-1}\right)$ separated on a HP-5MS polysiloxane-based column (temperature

Table 2

Chemical properties of the biochar applied to the experimental site.

\begin{tabular}{|c|c|c|c|c|c|c|c|c|}
\hline \multicolumn{2}{|l|}{$\mathrm{pH}$} & $\mathrm{Ca}$ & $\mathrm{Mg}$ & $\mathrm{Al}$ & $\mathrm{H}+\mathrm{Al}$ & \multirow{2}{*}{$\frac{\mathrm{P}_{(\text {Mehlich 1) }}}{\mathrm{mg} \mathrm{kg}^{-1}}$} & Exchangeable K & \multirow[t]{2}{*}{$\mathrm{Cu}$} \\
\hline $\mathrm{H}_{2} \mathrm{O}$ & $\mathrm{KCl}(1 \mathrm{M})$ & \multicolumn{4}{|c|}{$\mathrm{g} \mathrm{kg}^{-1}$} & & & \\
\hline 7.2 & 6.15 & 1.86 & 0.37 & 0 & 0 & 126.5 & 1547 & 0.39 \\
\hline $\mathrm{Zn}$ & $\mathrm{Fe}$ & \multirow{2}{*}{\multicolumn{2}{|c|}{ Mn }} & $C_{\text {tot }}$ & \multirow[t]{2}{*}{$\mathrm{N}_{\text {tot }}$} & $\mathrm{NH}_{4}^{+}$ & $\mathrm{NO}_{3}^{-}$ & $\mathrm{EC}^{\mathrm{a}}$ \\
\hline \multicolumn{2}{|c|}{$\overline{\mathrm{mg} \mathrm{kg}} \mathrm{kg}^{-1}$} & & & $\%$ & & \multicolumn{2}{|c|}{$\mathrm{mg} \mathrm{kg}^{-1}$} & $\mu \mathrm{cm}^{-1}$ \\
\hline 2.94 & 25.20 & 4. & & 74.3 & 1.18 & 17.4 & 0 & 3573 \\
\hline
\end{tabular}

${ }^{\mathrm{a}} \mathrm{EC}=$ electrical conductivity $\left(\mu \mathrm{S} \mathrm{cm}^{-1}\right)$. 
program $60-325^{\circ} \mathrm{C}$ at $20^{\circ} \mathrm{C} \mathrm{min}{ }^{-1}, 5$ min dwell time) and identified using an Agilent 5975B mass spectrometer operating in $70 \mathrm{eV}$ electron impact mode.

The main peaks in the pyrolysis chromatograms ("pyrograms") were identified on the basis of Py-GC-MS literature of pyrogenic C and NIST'05 library, and quantified using their primary ion fragment or fragments $(\mathrm{m} / \mathrm{z})$. Relative proportions of each pyrolysis product are expressed as percentage (\%) of total quantified peak area (TQPA).

\subsection{Experimental design and characteristics of treatments}

Five rates of biochar $\left(0,5,10,20\right.$ and $\left.40 \mathrm{Mg} \mathrm{ha}^{-1}\right)$ were applied once (in September 2011) to the respective plots sorted out in a randomized complete block design with four replications. Prior to its application, biochar was crushed into small pieces and forced to pass through a $2 \mathrm{~mm}$ sieve. During field application, plastic canvases were used as wind barriers to prevent dispersion. Biochar was immediately incorporated into the top $10 \mathrm{~cm}$ of soil with hoes prior to soybean sowing. The control plots ( $0 \mathrm{Mg} \mathrm{ha}^{-1}$ biochar) were also hoed.

\subsection{Soil sampling}

After soybean harvest at CS1 and CS4, soil samples were collected from the $0-10 \mathrm{~cm}$ layer with an auger. From the three central planting lines within each plot, twelve soil cores were collected and pooled to form a composite sample for each treatment plot. These samples were sieved through a $2 \mathrm{~mm}$ screen to remove soybean roots, air-dried and stored at room temperature prior to chemical analyses. Undisturbed soil samples were also taken after CS4 from the $0-10 \mathrm{~cm}$ layer in order to determine soil bulk density as described by Sisti et al. (2004) for the calculation of SOC stocks.

\subsection{Enzymatic activity}

Fluorescein diacetate hydrolysis was determined according to the method of Schnürer and Rosswall (1982), which is based on the spectrophotometric determination of hydrolyzed FDA in a $5 \mathrm{~g}$ soil sample. Dehydrogenase activity was determined using the method described in Casida et al. (1964), which is based on the spectrophotometric determination of triphenyltetrazolium formazan (TTF) released by $5 \mathrm{~g}$ of soil during $24 \mathrm{~h}$ at $37^{\circ} \mathrm{C}$.

\subsection{Field $\mathrm{CO}_{2}$ emission measurements using IRGA}

To quantify the soil $\mathrm{CO}_{2}$ flux in the field, a $10.3 \mathrm{~cm}$-diameter and $6 \mathrm{~cm}$-high PVC collar was inserted $2 \mathrm{~cm}$ into the soil in each field plot. Collars were inserted monthly from October-2012 to January-2013 (CS4) on the day before measurements to ensure that no overestimation of $\mathrm{CO}_{2}$ emissions would occur due to recent soil disturbance. Irrigation of the plots ceased always on the afternoon of the same day of collars insertion, in order to ensure similar water content at every measurement. $\mathrm{CO}_{2}$ flux measurements were performed always from 6:00 to 9:00 o'clock in the morning, to avoid large fluctuations in soil temperature. A portable infrared gas analyzer (IRGA) LI-6400/LI6400XT Version 6 (LI-COR, Lincoln, NE, USA) coupled to a Soil $\mathrm{CO}_{2}$ Flux Chamber was used to quantify soil $\mathrm{CO}_{2}$ emissions (Norman and Kucharik, 1997) at 15, 43, 71 and 106 days after plant emergence throughout CS4. At each measurement, values were corrected for ambient $\mathrm{CO}_{2}$ concentration.

\subsection{Carbon isotope analysis}

After removing soybean plant fragments coarser than $2 \mathrm{~mm}$ by sieving, bulk soil samples were oven-dried at $65{ }^{\circ} \mathrm{C}$, ground in a ball mill, and analyzed for $\mathrm{C}$ content and ${ }^{13} \mathrm{C}$ abundance. Analysis of ${ }^{13} \mathrm{C}$ abundance is an effective way to discriminate the origin of $\mathrm{C}$ in biochar-amended soils or the origin of its evolved $\mathrm{CO}_{2}$. Differences in ${ }^{13} \mathrm{C} /{ }^{12} \mathrm{C}$ ratios can be estimated from individual ${ }^{13} \mathrm{C} /{ }^{12} \mathrm{C}$ ratios relating to photosynthetic pathways of the plants generating the biochar feedstock, and the pathways of plants historically associated with the soil amended with biochar. The $\mathrm{C}$ contents and ${ }^{13} \mathrm{C}$ abundance of the soil samples was determined on aliquots containing between 200 and $400 \mu \mathrm{g}$ total $\mathrm{C}$ using an elemental analyzer coupled to a mass spectrometer Finnigan Mat Model delta-E. Results of natural abundance of ${ }^{13} \mathrm{C}$ were expressed in delta units, calculated as $\delta^{13} \mathrm{C}\left[\left(\mathrm{R}_{\text {sample }} / \mathrm{R}_{\text {standard }}\right)-\right.$ 1] $\times 1000(\%)$, where $R_{\text {sample }}$ and $R_{\text {standard }}$ are the ratios of ${ }^{13} \mathrm{C} /{ }^{12} \mathrm{C}$ of the study sample and the reference standard, respectively (Sisti et al., 2004).

We used the control treatments for the calculating the turnover in the SOC stock. We used the ${ }^{13} \mathrm{C}$ signature of the controls at CS1 and CS4 for calculations of the biochar stocks and decomposition rate. The relative contribution (\%) of $\mathrm{C}$ derived from native $\mathrm{SOC}\left(\mathrm{C}_{\mathrm{SOC}}\right)$ and biochar- $\mathrm{C}$ derived from biochar was estimated from the ${ }^{13} \mathrm{C}$ abundance of the soil samples with the following formula (Balesdent and Mariotti, 1996):

$\mathrm{C}_{\mathrm{SOC}}=\left(\delta^{13} \mathrm{C}_{\mathrm{M}}-\delta^{13}\right.$ biochar-C $) /\left(\delta^{13} \mathrm{C}_{\mathrm{SOC}}-\delta^{13}\right.$ biochar-C $)$

where $\mathrm{C}_{\mathrm{SOC}}$ is the proportion of $\mathrm{C}$ derived from the native SOC, $\delta^{13} \mathrm{C}_{\mathrm{M}}$ is the ${ }^{13} \mathrm{C}$ abundance of the biochar-amended soil, $\delta^{13}$ biochar- $\mathrm{C}$ is the ${ }^{13} \mathrm{C}$ abundance of biochar-C and $\delta^{13} \mathrm{C}_{\mathrm{SOC}}$ is the ${ }^{13} \mathrm{C}$ abundance of the soil with soybean crop in CS1 (January 2012) or CS4 (January 2013).

We also calculated the stock of native SOC $(0-10 \mathrm{~cm})$ by the following formula:

$\mathrm{S}_{\mathrm{C} 4}=\mathrm{S}_{\mathrm{T}} \times C_{\mathrm{SOC}}$

where $\mathrm{S}_{\mathrm{C} 4}$ is the stock of $\mathrm{C}_{4}$-derived carbon $\left(\mathrm{Mg} \mathrm{ha}^{-1}\right), \mathrm{S}_{\mathrm{T}}$ the total $\mathrm{C}$ stock (Mg ha $\left.{ }^{-1}\right)$.

\subsection{Statistical analyses and calculations}

Statistical analyses were performed using SAS 9.2 (SAS Institute, 2009). The stocks of native SOC and biochar-C $\left(\mathrm{Mg} \mathrm{ha}^{-1}\right)$ across the different biochar treatments and for both cropping cycles were analyzed using a two-way ANOVA with the PROC GLM $(\alpha=0.05)$. The relative decomposition rate of biochar was estimated using the formula $\mathrm{k}=-$ $\left(\ln \mathrm{S}_{\mathrm{CS} 4}-\ln \mathrm{S}_{\mathrm{CS} 1}\right) /\left(\mathrm{t}_{4}-\mathrm{t}_{1}\right)$, where $\mathrm{S}_{\mathrm{CS} 4}$ is the biochar-C stock after $\mathrm{CS} 4, \mathrm{~S}_{\mathrm{CS} 1}$ is the biochar-C stock after CS1 and $\mathrm{t}_{4}-\mathrm{t}_{1}$ are the times passed between the two sampling moments (one year). For the $\mathrm{CO}_{2}$ emissions, an average value was calculated across the measurements. Emissions of $\mathrm{CO}_{2}$ were expressed taking the total of soil organic matter (native $\mathrm{SOC}$ plus biochar) in the control and treatments into account.

\section{Results}

\subsection{Properties of biochar}

The major pyrolysis products and their relative abundances (\% of TQPA) are provided in Table 3. Phenols were the most abundant compound group (28.6\%) in the biochar, representing primarily demethoxylated lignin. The second most abundant group was composed by monocyclic aromatic hydrocarbons (MAHs) - benzene, toluene, C2-benzenes and C3-benzenes, which accounted for $13.7 \%$. Polycyclic aromatic hydrocarbons (PAHs), including naphthalene, indenes, benzofurans, biphenyl, fluorene, phenanthrene and anthracene, accounted for 3.3\%. The relatively large fractions of simple carbohydrates (13.0\%) and lignin moieties (17.0\%) indicated a low degree of thermal alteration. 
Table 3

Pyrolysis product obtained from the quantification of major peaks in the pyrograms of locally produced biochar. The relative proportions of the major groups are expressed as \% total quantified peak (TQPA), average of two replicates.

\begin{tabular}{lc}
\hline Pyrolysis product & \% of TQPA \\
\hline Acetic acid & 15.1 \\
Benzofurans & 2.4 \\
Carbohydrates & 13.0 \\
Guaiacyl lignin & 13.2 \\
Syringyl lignin & 3.8 \\
Monocyclic aromatic hydrocarbon & 13.7 \\
Methylene chain compound & 2.3 \\
Nitrogen-containing compound & 2.1 \\
Polycyclic aromatic hydrocarbon & 3.3 \\
Phenol (including catechol) & 28.5 \\
Unidentified compounds & 2.6 \\
\hline
\end{tabular}

\subsection{Native SOC and biochar-C stocks}

The control soil collected at the end of CS1 and CS4 showed a ${ }^{13} \mathrm{C}$ abundance, respectively, of $-18.51 \%$ ( $S E \pm 0.2 \%$ ) and $-20.31 \%$ 。 ( $\mathrm{SE} \pm 0.2 \%$ ). Soybean showed a ${ }^{13} \mathrm{C}$ abundance of $-26.50 \%$ ( unpublished results) and biochar of $-28.66 \%$. Soybean productivity was not affected by biochar treatments (Table S1; Supplementary information), and therefore, we assumed that soybean did not affect ${ }^{13} \mathrm{C}$ abundance differently among treatments.

Stocks of native SOC did not change significantly $(P=0.60)$ across the cropping seasons. Stocks of native SOC were also not significantly $(P=0.14)$ affected by biochar addition rates. Stocks of biochar-C significantly increased $(P<0.01)$ with biochar additions rates in both cropping seasons (Fig. 2). They significantly $(P<0.05)$ decreased from CS1 to CS4 at all biochar application rates. There was no significant biochar $\mathrm{x}$ CS interaction $(P>0.05)$.

\subsection{Native SOC and biochar decomposition rates}

On the basis of the changes in ${ }^{13} \mathrm{C}$ signature of the controls, we calculated a relative decomposition rate for native SOC of 0.22 year $^{-1}$. Biochar decomposition tended to decrease with higher amounts of biochar added to the soil (Fig. 3), however the differences between the treatments were statistically not significant $(P=0.136)$. The relative decomposition rate, average over all biochar treatments, was 0.32 1.00 year $^{-1}$, which is higher than that of native SOC.

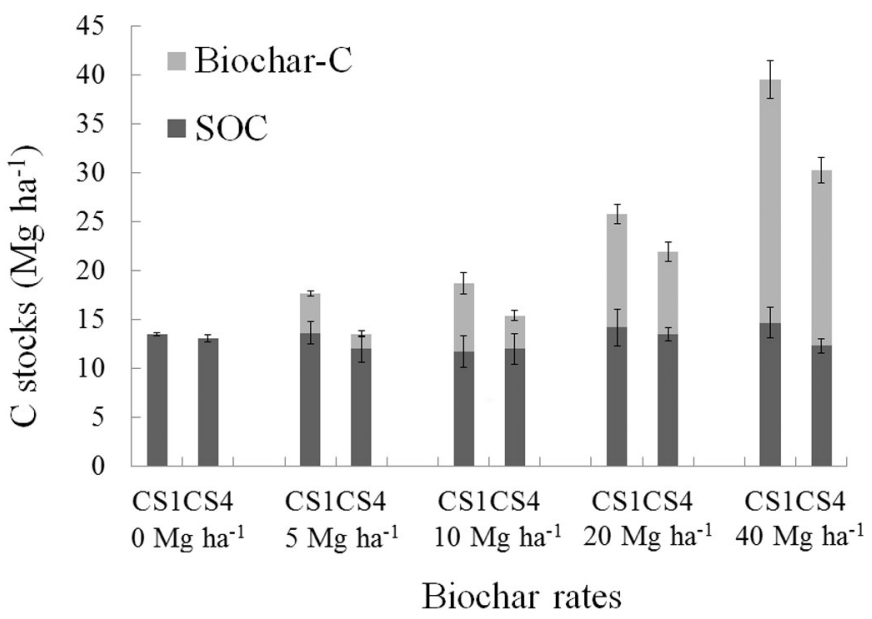

Fig. 2. Soil organic carbon (SOC) and biochar carbon (C) stocks at the 1st and 4th cropping seasons (CS) in soil amended with different rates of biochar. Vertical bars are standard error of the mean $(n=4)$.

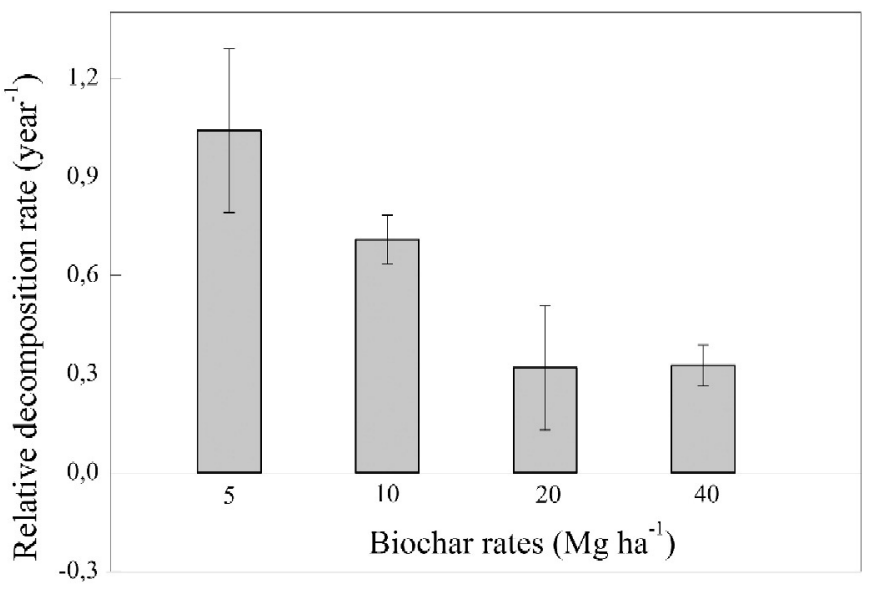

Fig. 3. Relative decomposition rate $(-\mathrm{k})$ between the 1 st and 4 th cropping cycles of biochar in soils amended with different rates of biochar. Vertical bars are standard error of the mean $(n=4)$.

\section{4. $\mathrm{CO}_{2}$ emissions from biochar-amended soils}

There were no significant differences in $\mathrm{CO}_{2}$ emission between the different treatments. On a relative scale, therefore, the amount of $\mathrm{CO}_{2}$ emitted per unit of soil C (native SOC plus biochar) declined (Fig. 4), suggesting that the biochar that was present at CS4 was degraded more slowly than the native SOC.

\subsection{Enzymatic activity}

There was no significant effect of biochar rates, CS or their interaction on DHG activity (Fig. 5a). For FDA, there was a significant $(P<0.01)$ effect of the CS only (Fig. 5b). The FDA activity was higher at the end of the CS1, compared to the CS4. No significant effects of biochar or the biochar x CS interaction were observed.

\section{Discussion}

The biochar that was produced in a local traditional kiln was much less thermally altered than has generally been claimed for biochar. It is

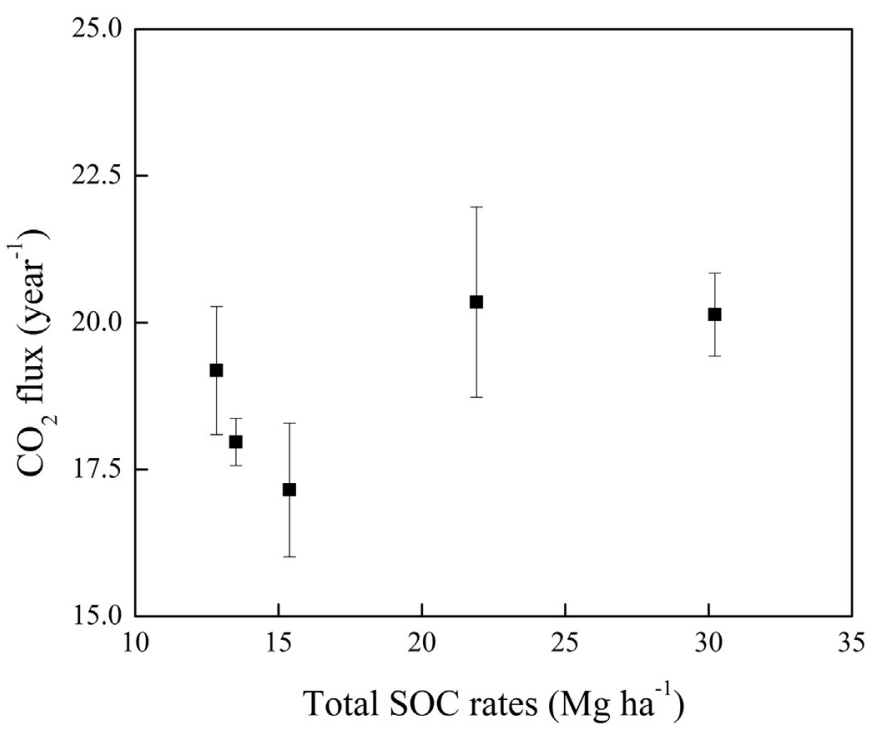

Fig. 4. The $\mathrm{CO}_{2}$ flux from soil organic carbon (SOC) amended with different rates of biochar one year after application. Vertical bars represent the standard error of the mean $(n=4)$. 

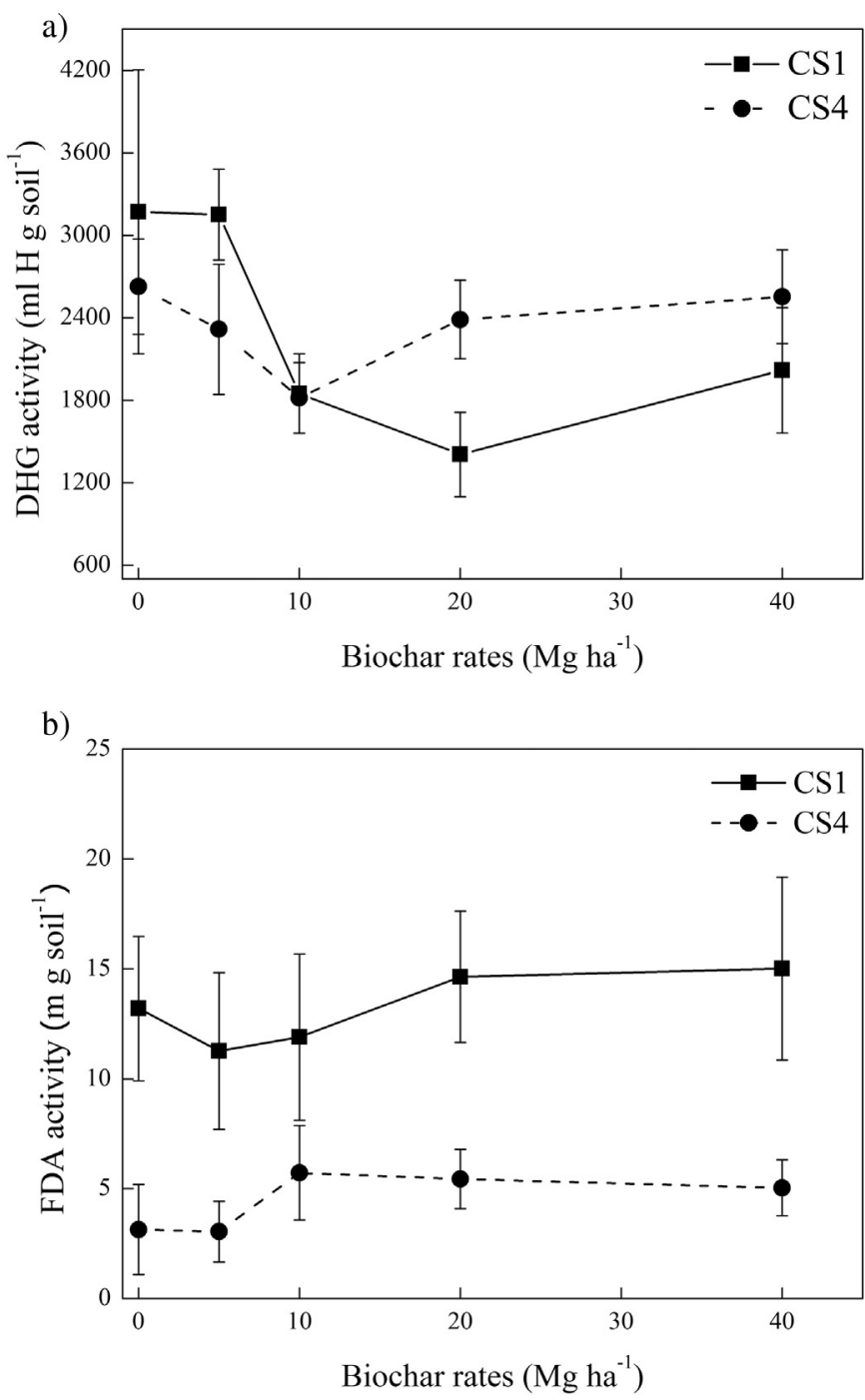

Fig. 5. Enzymatic activity at different biochar rates in the 1st and 4th cropping seasons (CS). A = dehydrogenase (DHG); B = fluorescein diacetate (FDA). Vertical bars are standard error of the mean $(n=4)$.

assumed (Swami et al., 2009) that such local kilns char material at around $500{ }^{\circ} \mathrm{C}$. However, the characteristics of the material (Table 3) are similar to those of biochar pyrolysed at $400{ }^{\circ} \mathrm{C}$ (Kaal et al., 2012). The proportion of MAHs (13.7\% of TQPA; Table 3) is low for a biochar produced at $500{ }^{\circ} \mathrm{C}$ (Kaal et al., 2012). The presence of lignin, including guaiacyls with an intact C3-side chain, is a further strong indication that a significant part of the lignin had undergone very little thermal rearrangement. Biochar produced in traditional kilns is assumed to be similar to biochar produced under optimal pyrolysis conditions in the laboratory (Lehmann et al., 2006). Our results show that biochar produced in traditional kilns is not equivalent to that produced under laboratory conditions at similar pyrolysis temperatures, with major consequences for the assessment of its climate change mitigation potential.

The decay rate of biochar was larger $\left(\mathrm{k}=0.32-1.0\right.$ year $\left.^{-1}\right)$ than the decay of the native SOC $\left(k=0.22\right.$ year $^{-1}$; Fig. 3$)$. These results are in line with other field studies that also reported a high decomposition rate $\left(\mathrm{k}=0.01\right.$ to 0.38 year $^{-1}$ ) of charcoal (Bird et al., 1999; Nguyen et al., 2008; Major et al., 2010). These losses are much higher than the 10 to $20 \%$ within $5-10$ years as proposed by Lehmann et al. (2006) and the decay rate $\left(\mathrm{k}=0.005-0.0005\right.$ year $\left.^{-1}\right)$ suggested by Kuzyakov et al. (2009) that were used to argue that biochar application sequesters substantial amounts of carbon.
It is an important issue how these large discrepancies in decomposition rate of biochar can be explained. Major et al. (2010) suggested that the large biochar loss in their study was due to physical movement (leaching, run off) rather than biological degradation. In a two-year field experiment, they found a loss of biochar ranging from 53\% with low biochar application rates $\left(11.6 \mathrm{Mg} \mathrm{ha}^{-1}\right.$ ) to $20 \%$ with high application rates $\left(116.1 \mathrm{Mg} \mathrm{ha}^{-1}\right.$ ), resulting in a decomposition rate of 0.38 and 0.11 year $^{-1}$ respectively. A small fraction of these losses was attributed to leaching (up to 1\%). Surface runoff was suggested as the main explanation for biochar loss; however the authors did not measure the runoff intensity.

In our study, decomposition was the most likely cause for the observed decrease in biochar stocks (Fig. 2). The experimental period was unusually dry, and except for 2 months (February and March 2012), water supply was complemented by irrigation (Fig. 1). Irrigation avoided both excess water (and biochar) leaching and surface runoff, as only enough water to meet crop requirements was applied. The absence of leaching is confirmed by potential evapotranspiration rates similar to the amount of water available to the crop (Fig. 1). It is also unlikely that decreases in the biochar stocks were caused by biochar effects on soil bulk density, as this variable was not affected by the treatments (Supplementary Table S1).

In addition to the quality of biochar, its decomposition rate will depend on ecosystem properties, as suggested for SOC (Schmidt et al., 2011). In our field conditions, soil temperatures were high, there was no water limitation, and the soil was sandy with very low amounts of clay. In such environments, the decomposition of biochar is likely fast. Bird et al. (1999) estimated charcoal half-life (for large particles, i.e., $>2000 \mu \mathrm{m}$ ) in sandy soils as $<50$ year (equivalent to $\mathrm{k}>0.01$ year $^{-1}$ ). Zimmermann et al. (2012) estimated a half-life of 46 years (equivalent to $\mathrm{k}>0.01$ year $^{-1}$ ) for pyrogenic carbon in tropical savannah environments. These estimates refer to fire-derived charcoal, however these estimates are comparable to ours on the long-term. Pyrogenic carbon tends to decompose faster in unsaturated and warmer environments than in saturated and colder environments (Glaser and Amelung, 2003; Nguyen et al., 2008). Although fast turnover rates of pyrogenic carbon have been observed in clay loam soils (Knicker et al., 2013), in fine-textured soils, biochar may be chemically and physically protected against decomposition similar to SOC (Schmidt et al., 2011), through interactions with mineral surfaces and aggregate formation. Pessenda et al. (2001) estimated a residence time of thousands of years for charcoal in fine-textured fossil soils. Therefore, lack of protection in sandy soils may have further enhanced the decomposition rates of biochar in our study.

Our data highlight the rapid decomposition of a large fraction of biochar produced under traditional methods. Data from Fig. 4 suggest that after 1.5 years the remaining biochar is composed of a recalcitrant fraction, as the emissions of $\mathrm{CO}_{2}$ do not change with increasing amounts of applied biochar.

Stocks of SOC were not affected by addition of biochar, suggesting that biochar addition unlikely causes loss of native SOC through priming. Negative priming was also not observed. These data are consistent with the absence of effects of biochar addition on enzyme activities (Fig. 5) and microbial C (Supplementary Fig. S1).

Both the study of Major et al. (2010) and our study suggest a decline in biochar decomposition rates with increasing amounts added; however, in both cases the differences were not statistically significant. This possible effect merits further study, the more so because a metaanalysis by Sagrilo et al. (2014) provided evidence that the biochar-C : SOC ratio (in this study ranged from 0.13 to 1.7 ) was the major determinant in affecting the magnitude of the increase in $\mathrm{CO}_{2}$ emissions of soil amended with PyOC. However, the estimates of the decomposition rate should be evaluated carefully. The ${ }^{13} \mathrm{C}$ isotopic differences between controls and biochar treatments, where low amounts of biochar ( 5 and $10 \mathrm{Mg} \mathrm{ha}^{-1}$ ) were added, were relatively small, compared to the analytical error in ${ }^{13} \mathrm{C}$ measurements (c.v. $=2 \%$, based on 12 measurements of 
the same standard sample), resulting in large confidence intervals in the estimate of biochar decomposition.

\section{Conclusions}

In conclusion, we demonstrated, under field conditions, that locally produced biochar can have high decomposition rates, comparable to or even higher than that of native SOC. We further conclude that in order to scale-up biochar projects for soil carbon sequestration, there is a need for further data from field experiments, in which locally produced biochar is tested. This is especially relevant considering that such materials may be the most abundant form of biochar in many countries like Brazil. Scaling up carbon sequestration potential of biochar based on materials produced under controlled conditions and tested in the lab, may result in unwarranted confidence in biochar as a major contribution to climate change mitigation.

\section{Acknowledgments}

We acknowledge the Banco do Nordeste (2010/135 - FUNDECI) for financing this research. E. Sagrilo is grateful to Embrapa for supporting his PhD fellowship. T. F. Rittl is grateful to CAPES (559410-3) for supporting her PhD scholarship. We thank the Terra Preta Programme of Wageningen University for supporting this research. We also thank Joeri Kaal for helping to interpret the pyrograms and Kor Zwart for useful suggestions on the manuscript. The authors also thank the referees for their comments on the manuscript.

\section{Appendix A. Supplementary data}

Supplementary data to this article can be found online at http://dx. doi.org/10.1016/j.geodrs.2015.08.006.

\section{References}

Andrade Junior, A.S., de Bastos, E.A., Barros, A.H.C., Silva, C.O., da Gomes, A.A.N., 2005. Classificação climática e regionalização do semi-árido do Estado do Piauí sob cenários pluviométricos distintos 1 Climatic classification and semiarid zone regionalization of the Piauí State, Brazil, Material e Métodos. Rev. Ciência Agronômica 36, 143-151.

Balesdent, J., Mariotti, A., 1996. Measurement of soil organic matter turnover using ${ }^{13} \mathrm{C}$ natural abundance. In: Boutton, T.W., Yamasaki, S.I. (Eds.), Mass Spectrometry of Soils. Marcel Dekker, New York, pp. 83-111.

Bird, M.I., Moyo, C., Veenendaal, E.M., Lloyd, J., Frost, P., 1999. Stability of elemental carbon in a savanna soil. Global Biogeochem. Cycles 13, 923-932.

Casida, L.E., Klein, D.A., Santoro, T., 1964. Soil dehydrogenase activity. Soil Sci. 98, 371-378.

Cross, A., Sohi, S.P., 2011. The priming potential of biochar products in relation to labile carbon contents and soil organic matter status. Soil Biol. Biochem. 43, 2127-2134.

Duboc, E., Costa, C.J., Veloso, R.F., Oliveira, L.S., Paludo, A., 2007. Panorama Atual da Produção de Carvão Vegetal no Brasil e no Cerrado (No. Documentos 197), Embrapa Documentos 197

EMBRAPA, 1997. Manual de métodos de análise de solo. Emprapa solos, Rio de Janeiro, p. 212.

Glaser, B., Amelung, W., 2003. Pyrogenic carbon in native grassland soils along a climosequence in North America. Global Biogeochem. Cycles 17, 1064-1071.

Hilscher, A., Knicker, H., 2011. Carbon and nitrogen degradation on molecular scale of grass-derived pyrogenic organic material during 28 months of incubation in soil. Soil Biol. Biochem. 43, 261-270.

Hilscher, A., Heister, K., Siewert, C., Knicker, H., 2009. Mineralisation and structural changes during the initial phase of microbial degradation of pyrogenic plant residues in soil. Org. Geochem. 40, 332-342.
Jones, D.L., Murphy, D.V., Khalid, M., Ahmad, W., Edwards-Jones, G., DeLuca, T.H., 2011 Short-term biochar-induced increase in soil $\mathrm{CO}_{2}$ release is both biotically and abiotically mediated. Soil Biol. Biochem. 43, 1723-1731.

Kaal, J., Martínez Cortizas, A., Nierop, K.G.J., 2009. Characterisation of aged charcoal using a coil probe pyrolysis-GC/MS method optimised for black carbon. J. Anal. Appl. Pyrolysis 85, 408-416.

Kaal, J., Martínez Cortizas, A., Reyes, O., Soliño, M., 2012. Molecular characterization of Ulex europaeus biochar obtained from laboratory heat treatment experiments - a pyrolysis-GC/MS study. J. Anal. Appl. Pyrolysis 95, 205-212.

Knicker, H., González-Vila, F.J., González-Vázquez, R., 2013. Biodegradability of organic matter in fire-affected mineral soils of Southern Spain. Soil Biol. Biochem. 56, 31-39.

Kuzyakov, Y., Subbotina, I., Chen, H., Bogomolova, I., Xu, X., 2009. Black carbon decomposition and incorporation into soil microbial biomass estimated by ${ }^{14} \mathrm{C}$ labeling. Soil Biol. Biochem. 41, 210-219.

Lehmann, J., 2007. A handful of carbon locking. Nature 447, 10-11.

Lehmann, J., Joseph, S., 2009. Biochar for environmental management: an introduction. In: Lehmann, J., Joseph, S. (Eds.), Biochar for Environmental Management: Science and Technology. Routledge, pp. 1-12.

Lehmann, J., Gaunt, J., Rondon, M., 2006. Bio-char sequestration in terrestrial ecosystems-a review. Mitig. Adapt. Strateg. Glob. Chang. 11, 403-427.

Luo, Y., Durenkamp, M., De Nobili, M., Lin, Q., Brookes, P.C., 2011. Short term soil priming effects and the mineralisation of biochar following its incorporation to soils of different pH. Soil Biol. Biochem. 43, 2304-2314.

Major, J., Lehmann, J., Rondon, M., Goodale, C., Biology, E., 2010. Fate of soil-applied black carbon: downward migration, leaching and soil respiration. Glob. Chang. Biol. 16, 1366-1379.

Melo, F. de B., Cavalcante, A.C., Andrade Junior, A.S., de Bastos, E.A., 2004. Levantamento Detalhado dos Solos da Área da Embrapa Meio-Norte. (No. Documentos 89), Embrapa - Documentos 89.

Méndez, a, Tarquis, a M., Saa-Requejo, a, Guerrero, F., Gascó, G., 2013. Influence of pyrolysis temperature on composted sewage sludge biochar priming effect in a loamy soil. Chemosphere 93, 668-676.

Nguyen, B.T., Lehmann, J., 2009. Black carbon decomposition under varying water regimes. Org. Geochem. 40, 846-853.

Nguyen, B.T., Lehmann, J., Kinyangi, J., Smernik, R., Engelhard, M.H., 2008. Long-term black carbon dynamics in cultivated soil. Biogeochemistry 89, 295-308.

Norman, J., Kucharik, C., 1997. A comparison of six methods for measuring soil-surface carbon dioxide fluxes. J. Geophys. Res. 102, 771-777.

Pessenda, L.C.R., Gouveia, S.E.M., Aravena, R., 2001. Radiocarbon dating of total soil organic matter and humin fraction and its comparison with ${ }^{14} \mathrm{C}$ ages of fossil charcoal. Radiocarbon 43, 595-601.

Richards, L.A., 1954. Diagnosis and improvement of saline and alkali soils, Agriculture Handbook 60. United States Salinity Laboratory, Washington, USA

Sagrilo, E., Jeffery, S., Hoffland, E., Kuyper, T.W., 2014. Emission of $\mathrm{CO}_{2}$ from biocharamended soils and implications for soil organic carbon. GCB Bioenergy http://dx doi.org/10.1111/gcbb.12234 (n/a-n/a).

Schmidt, M.W.I., Torn, M.S., Abiven, S., Dittmar, T., Guggenberger, G., Janssens, I.A., Kleber M., Kögel-Knabner, I., Lehmann, J., Manning, D.A.C., Nannipieri, P., Rasse, D.P., Weiner, S., Trumbore, S.E., 2011. Persistence of soil organic matter as an ecosystem property. Nature 478, 49-56.

Schnürer, J., Rosswall, T., 1982. Fluorescein diacetate hydrolysis as a measure of total microbial activity in soil and litter. Appl. Environ. Microbiol. 43, 1256-1261.

Sisti, C.P.J., dos Santos, H.P., Kohhann, R., Alves, B.J.R., Urquiaga, S., Boddey, R.M., 2004 Change in carbon and nitrogen stocks in soil under 13 years of conventional or zero tillage in southern Brazil. Soil Tillage Res. 76, 39-58.

Smith, J.L., Collins, H.P., Bailey, V.L., 2010. The effect of young biochar on soil respiration. Soil Biol. Biochem. 42, 2345-2347.

Swami, S.N., Steiner, C., Teixeira, W.G., Lehmann, J., 2009. Charcoal making in the Brazilian Amazon: economic aspects of production and carbon conversion efficiencies of kilns. Earth 411-422.

Woolf, D., Amonette, J.E., Street-Perrott, F.A., Lehmann, J., Joseph, S., 2010. Sustainable biochar to mitigate global climate change. Nat. Commun. 1, 1-9.

Zimmerman, A.R., Gao, B., Ahn, M.-Y., 2011. Positive and negative carbon mineralization priming effects among a variety of biochar-amended soils. Soil Biol. Biochem. 43, 1169-1179.

Zimmermann, M., Bird, M.I., Wurster, C., Saiz, G., Goodrick, I., Barta, J., Capek, P., Santruckova, H., Smernik, R., 2012. Rapid degradation of pyrogenic carbon. Glob. Chang. Biol. 18, 3306-3316. 